DOI 10.18551/rjoas.2020-08.12

\title{
BANK 4.0 EXPERIENTIAL QUALITY AND ITS EFFECT ON WORD OF MOUTH BEHAVIOR, SATISFACTION AND INTENTIONS
}

\author{
Abdillah Luthfi, Postgraduate Student \\ Hussein Ananda Sabil, Ratnawati Kusuma, Associate professors \\ Faculty of Economics and Business, University of Brawijaya, Indonesia \\ *E-mail: luthfipamotan@gmail.com \\ ORCID: 0000-0003-1678-325X
}

\begin{abstract}
Bank 4.0 is a modern banking platform that is based entirely on digital technology with absolutely no physical interaction between customers and banks. Since 2017, Bank 4.0 has grown rapidly in Indonesia. However, it raises new concerns as the emergence of issues related to Bank 4.0 experiential quality. This research aims at determining the effects of Bank 4.0 experiential quality on word of mouth behavior, customer satisfaction and continuance intention based on perception of millennial customer in Indonesia. Quantitative method was used in this research by using the multivariate data analysis technique. Data collected from 673 millennial customers who have access to Bank 4.0 applications. This research discovered that Bank 4.0 experiential quality has been empirically proven to directly affect word of mouth behavior, customer satisfaction and continuance intention. This research is the first study that explored Bank 4.0 experiential quality and its effects on three main variables in marketing, namely, word of mouth behavior, continuance intention, and customer satisfaction, based on millennial customer perceptions. The results from this study can help Bank 4.0 to improve marketing performance through experiential quality.
\end{abstract}

\section{KEY WORDS}

Bank 4.0, millennial customers, customer experience, Indonesian bank, newest banking, customer satisfaction, continuance intention, customer behavior.

The advancement of information technology in the 4.0 era has encouraged banks to improve their services; one of them is by establishing electronic banking services. With the rapid development of technology in the financial industry, it is very important for banks to develop electronic banking services to facilitate easier management and operations, provide added value to customers, be more flexible, and reduce technical errors (Nguyen, 2020). Fierce competition between banks and customers that are increasingly demanding have motivated banks to apply digital services, such as telephone banking, internet banking, and mobile banking, in order to provide better services to customers (Alalwan et al, 2016). When customer expectations and bank competition increase, attracting new customers, retaining current customers, and increasing profits become important after the 2008 financial crisis (Monferrer-Tirado et al, 2016). Banks are also competing to innovate and improve efficiency in various posts.

Supported by advanced information technology and increasingly sophisticated smartphones, the banking industry is now entering an era, which according to Brett King (2018) in his world best seller book titled "Bank 4.0: Banking Every Where, Never at Bank", is called the era of Bank 4.0. The definition of Bank 4.0 referred to by King (2018) is the terminology of unlimited banking access wherever and whenever that is supported by artificial intelligence with no need for physical distribution where commercial banks are only one of them. In the past 3 years, the development of Bank 4.0 in Indonesia seems unstoppable. Based on research of MDI Ventures \& Mandiri Sekuritas (2017), the penetration of smartphone-based financial transactions has exceeded conventional bank transactions since 2017. On the one hand, the presence of Bank 4.0 is eagerly awaited and welcomed, especially by the millennial generation, but on the other hand, the presence of Bank 4.0 also raises new concerns in the financial industry (King, 2018). If these problems 
are not immediately addressed, they will raise serious concerns that threaten the sustainability of Bank 4.0 in Indonesia. In order to help the growth of Bank 4.0 industry, which is manifested in an increase in the number of customers and market share and characterized by an increase in the experiential quality and customer satisfaction and loyalty (Mbama et al, 2018), this research was conducted. This research focused on Bank 4.0 experiential quality based on the perspective of millennial customers and their effects on continuance intention, word of mouth (WOM) behavior, and customer satisfaction.

\section{LITERATURE REVIEW}

Bank 4.0 is a modern banking platform, which requires no physical encounter at all between banks and customers (King, 2018). The physical existence of branch offices and other premises is not needed in this Bank 4.0 era. Bank's service paradigm has changed from tangible to intangible (service), so it is very suitable to be approached with the S-D Logic theory. The core of S-D logic is the idea that all exchanges are best understood in terms of service-for-service exchange, the reciprocal application of resources for the benefit of others (Vargo \& Lusch, 2004). One of the S-D Logic premises is 'the customer is always a co-creator of value', where this 'co-creator' will only show if there is active participation by the customer, which in turn will create experiential quality.

Customer experience is customer's cognitive and affective assessment of all direct and indirect encounters with the firm relating to their purchasing behavior (Klaus and Maklan, 2013). Some experts have observed the dimensions of experience, including: sensory, affective, intellectual and behavioral (Brakus et al., 2009); environment, benefit, accessibility, convenience, utility, incentive, and trust (Knutson et al., 2007); sense, feel, think, act, and relate (Schmitt, 1999). The many differences in the results of these studies, which mean that there has been no consensus among experts, are research gap, which opens up opportunities for researchers to examine the dimensions of Bank 4.0 experiential quality further. Based on previous research that has been conducted prior to this research, six attributes were empirically proven as the dimensions of Bank 4.0 experiential quality: functional quality, convenience, innovations, trust, value, risk mitigation and security.

King (2018) defined Bank 4.0 as an embedded, ubiquitous banking delivered in realtime through the technology layer. This banking is dominated by real-time, contextual experiences, frictionless engagement and a smart, artificial intelligence - based advice layer and is largely digital omni-channel with zero requirements for physical distribution. Bank 4.0 is very different from digital banking where an online system is only limited as an alternative distribution channel for banks and physical encounters between banks and customers are absolutely necessary. Bank 4.0 is more than a place for storing money, means of payment, and credit utilities. Bank 4.0 is about the ability to access the utility of banking wherever and whenever you need a money solution, in real time, tailored to your unique behaviors (King, 2018).

According to Harrison-Walker (2001), WOM is informal, person-to-person communication between a non-commercial communicator and a receptor about a brand, a product, an organization, or a service. WOM behavior also means saying something positive, recommending and ensuring others that you do business with XYZ (Klaus \& Maklan, 2013; Brown et al, 2005; Mbama et al, 2018). Hence, this research proposed:

H1. Bank 4.0 experiential quality directly affects WOM behavior.

Customer satisfaction is the difference between an individual's expectations before consumption of a product or service and the actual experience that results after the consumption (Oliver, 1980), an overall evaluation based on the total purchase and consumption experience of the target product, or service performance compared with repurchase expectations over time (Sharma and Patterson, 2000); to keep customers happy (Kotler, 2003); and is the most influential factor on customer loyalty (Amin, 2010); affects customer loyalty through customer delight as mediator (Kim and Park, 2019). Hence, this research proposed:

H2. Bank 4.0 experiential quality directly affects customer satisfaction. 
H3. Customer satisfaction has a direct effect on WOM behavior.

$\mathrm{H} 4$. Customer satisfaction has a direct effect on continuance intention.

Continuance intention is the development of behavioral intention concept. Bhattacherjee (2001) defined continuance intention as an interest in continuing to participate or take part in a particular system. In general, continuance intention reflects post-adoption behavior and intention to continue using information systems (Limayem and Cheung, 2011). Measurement of continuance intention focuses on the purchase history of customer (Vesel and Zabkar, 2009; Fathollahzadeh et al., 2011) and continuance intention has been measured by the repeat buying behavior of customers towards a product or service $(\mathrm{Wu}$, 2011). Overall selection factor, external selection factor, and internal selection factor have a positive effect on repurchase intention (Kim and Yang, 2020). Experience value has a positive effect on behavioral intention (Tran, 2020). Hence, this research proposed:

H5. Bank 4.0 experiential quality directly affects continuance intention.

In this study, the millennial generation refers to the generation born during the period of 1980 to 2004, who grows up and is familiar with computers, online connected networks and social media (Burstein, 2013); and they are digital natives (Prensky, 2001 and King, 2018). They tend to easily adjust to new programs, operating systems (OS), and devices. Some experts identify millennial characteristics as: confident, connected, open to change (Lenhart et al.,2010); creative, connected, and confident (Ali dan Purwandi, 2016); technologically savvy, civic-oriented, conscious, global citizens, entrepreneurial, flexible, pragmatic idealists, authentic, transparent, progressive, confident, team-oriented, multi-taskers, impatient, adventurous (Korobka, 2018); mobile first, networks, expecting personalization, passionate about values (Lenhart et al, 2015; Fromm \& Garton, 2013; Smith, 2011); a dual propensity toward consumption (Kim and Yang, 2020). They were chosen as the subject of this study for the reasons: First, Bank 4.0 is identical to the application of contemporary technology, this is in accordance with their digital native character. Second, they are the main prospective customers of banking to come. Researching and capturing their opinions through their reactions and interactions with the Bank 4.0 services today is very important to understand their experiences and their impact on the development of Bank 4.0 in the future.

\section{METHODS OF RESEARCH}

This research employed questionnaires that were distributed via social media. Before the main questionnaires were distributed, a pilot test was conducted first. Content validity was tested first by holding discussions with two banking experts, research practitioners, and academics to ensure that the questionnaire items were complete, not ambiguous, and can be understood by respondents. Research was conducted in Malang, Indonesia, with the consideration that Malang is one of the centers of education with $45 \%$ of the population being the millennial generation (Statistics Indonesia (BPS), 2020). Research was conducted in May 2020 and as many as 44 respondents participated in the pilot test. Based on statistical tests, the Spearman's rank correlation ranged from 0.849 to 0.915 , meeting the criteria $>0.50$, and the Cronbach's alpha value was between 0.723 and 0.921 , meeting the criteria $\geq 0.70$ (Ghozali, 2014). Therefore, it can be concluded that the designed questionnaire had good validity and reliability, so that the main questionnaires were eligible to be distributed to target respondents.

Furthermore, the main questionnaires were distributed and as many as 688 respondents participated, but only 673 respondents met the criteria. The recommended sample size for marketing study tests is at least 200 (Malhotra, 2012), so that the sample size of 673 had met the minimum sample criteria. Partial least square was employed to analyze data with three-step analysis, namely: outer model, inner model, and hypothesis test. Outer model is for describing the relationship between indicator blocks and their latent variables by conducting a test for 3 indicators called convergent validity, discriminant validity, and uni-dimensionality. Meanwhile, inner model is for predicting causality between latent variables or testing a hypothesis by conducting test for 3 indicators, namely: coefficient of determination (R-square), predictive relevance (Q-square), and Goodness of Fit Index (GoF). 
The third step was hypothesis test. In this research, the confidence level was set at $95 \%$. A 5-point Likert scale was employed for measurement. Respondents specified their level of agreement to a statement typically in five points from 1 (strongly disagree) to 5 (strongly agree).

\section{RESULTS OF STUDY}

The demographic profile of the respondents is as follows: $60 \%$ of respondents were women, $57 \%$ of respondents aged $16-20$ years, $85 \%$ of the marital status of respondents was single, $70 \%$ of respondents were high school graduates, $59 \%$ of respondents were Instagram active users, and $49 \%$ of respondents were OVO customers. A more comprehensive demographic profiles are shown in Table 1.

Outer model evaluation was conducted by testing convergent and discriminant validities and unidimensionality of each item. Convergent analysis was tested by outer loading, which is said to be valid if the outer loading value for each item is above 0.7 and the Average Variance Extracted (AVE) score is above 0.5 for each construct (Hair et al., 2014). Based on the test results in this research, outer loading varied between 0.834 and 0.899 and AVE scores varied between 0.651 and 0,740 . The outer model test results are shown in Table 2.

The second step was to test discriminant validity, where the model is said to meet the criteria if the square root of AVE is greater than correlations between constructs (Fornell and Larker, 1981). Table 3 shows a comparison of the square root of AVE (which is in parentheses) and the correlation with other constructs. The results proved that the model in this research did not have discriminant validity issues. Unidimensionality test employed composite reliability to ensure that the constructs used are unidimensional. The model is said to have no unidimensionality issues if the constructs have composite reliability above 0.7 (Chin, 2010). Table 2 shows that composite reliability varied between 0.887 and 0.918 , so it can be said that all constructs were unidimensional.

Table 1 - Respondent Profile and Frequency Information

\begin{tabular}{|c|c|c|c|}
\hline Variable & Criteria & Frequency & Percentage \\
\hline \multirow{2}{*}{ Gender } & Male & 270 & 40.12 \\
\hline & Female & 403 & 59.88 \\
\hline \multirow{5}{*}{ Age } & $16-20$ & 381 & 56.61 \\
\hline & $21-25$ & 163 & 24.22 \\
\hline & $26-30$ & 58 & 8.62 \\
\hline & $31-35$ & 29 & 4.31 \\
\hline & $36-40$ & 42 & 6.24 \\
\hline \multirow{2}{*}{ Marital Status } & Single & 569 & 84.55 \\
\hline & Married & 104 & 15.45 \\
\hline \multirow{6}{*}{ Educational level } & Junior High School & 1 & 0.15 \\
\hline & Senior High School & 468 & 69.54 \\
\hline & College & 13 & 1.93 \\
\hline & University & 177 & 26.30 \\
\hline & Postgraduate & 12 & 1.78 \\
\hline & Doctorate & 2 & 0.30 \\
\hline \multirow{5}{*}{ Most used social media } & Facebook & 24 & 3.57 \\
\hline & Instagram & 396 & 58.84 \\
\hline & Twitter & 88 & 13.08 \\
\hline & YouTube & 119 & 17.68 \\
\hline & Others & 46 & 6.83 \\
\hline \multirow{7}{*}{ Most used Bank 4.0 application } & BRIMO & 46 & 6.84 \\
\hline & DANA & 45 & 6.69 \\
\hline & GoPay & 150 & 22.29 \\
\hline & Jenius & 21 & 3.12 \\
\hline & LinkAja & 38 & 5.65 \\
\hline & OVO & 331 & 49.18 \\
\hline & Others & 42 & 6.23 \\
\hline
\end{tabular}


Table 2 - Outer Loading, AVE, Composite Reliability

\begin{tabular}{|c|c|c|c|c|}
\hline Variable & Indicator & $\begin{array}{l}\text { Outer } \\
\text { Loading }\end{array}$ & AVE & $\mathrm{CR}$ \\
\hline \multirow{6}{*}{$\begin{array}{l}\text { WOM Behavior } \\
\text { (WOM) }\end{array}$} & $\begin{array}{c}\text { (WOM1) Mentioned to others that you do business with } \\
\text { Bank }\end{array}$ & 0.834 & \multirow{6}{*}{0.651} & \multirow{6}{*}{0,918} \\
\hline & $\begin{array}{c}\text { (WOM2) Made sure that others knew that you do } \\
\text { business with Bank }\end{array}$ & 0.825 & & \\
\hline & $\begin{array}{c}\text { (WOM3) Defending it against bad comments by strongly } \\
\text { supporting their choices }\end{array}$ & 0.749 & & \\
\hline & (WOM4) Spoke positively about Bank to others & 0.819 & & \\
\hline & (WOM5) Recommended Bank to acquaintances & 0.868 & & \\
\hline & (WOM6) Giving high NPS & 0.737 & & \\
\hline \multirow{3}{*}{$\begin{array}{l}\text { Customer Satisfaction } \\
\text { (CS) }\end{array}$} & (CS1) The sense of fulfillment & 0,881 & \multirow{3}{*}{0.740} & \multirow{3}{*}{0,895} \\
\hline & (CS2) Fewer complaints & 0,797 & & \\
\hline & (CS3) Overall satisfaction with products and services & 0,899 & & \\
\hline \multirow{3}{*}{$\begin{array}{l}\text { Continuance Intention } \\
(\mathrm{Cl})\end{array}$} & $\begin{array}{l}\text { (CI1) Repeated patronage of a certain bank over a long } \\
\text { period of time }\end{array}$ & 0,873 & \multirow{3}{*}{0.724} & \multirow{3}{*}{0,887} \\
\hline & (Cl2) Repetitive purchasing of products and services & 0,825 & & \\
\hline & (Cl3) Consider bank as the first choice to buy - services & 0,854 & & \\
\hline
\end{tabular}

Table 3 - The comparison between square root of AVE and correlations

\begin{tabular}{|c|c|c|c|}
\hline $\mathrm{n} / \mathrm{n}$ & Continuance intention & Customer satisfaction & WOM behavior \\
\hline Continuance intention & $(0.851)$ & & \\
\hline Customer satisfaction & 0.682 & $(0.860)$ & \\
\hline WOM behavior & 0.651 & 0.693 & $(0.807)$ \\
\hline
\end{tabular}

The next model test was the inner model evaluation, which was conducted by examining the coefficient of determination (R-square), predictive relevance (Q-square), and GoF. The first test was by using the coefficient of determination, which is categorized into three classes: 0.19 (weak), 0.33 (moderate), and 0.67 (substantial) (Chin et al., 2008). Based on PLS estimates, coefficient of determination for WOM behavior was perceived to be between moderate and substantial (R-square $=0.748)$, while customer satisfaction was perceived to be substantial $(\mathrm{R}$-square $=0.688)$ and continuance intention was perceived between moderate and substantial (R-square $=0.481)$. The second inner model test was conducted by using Stone-Geisser test of predictive relevance (Q-square), which explains how to measure the level of well-observed values which are restructured by the model and its parameters (Chin, 2010). Endogenous construct is said to have predictive relevance if $Q$ square is greater than 0 (Hair et al., 2014). In this research, Q-square values varied from 0.343 to 0.472 . Because the $Q$-square values were greater than 0 , it meant all constructs had predictive relevance. Meanwhile, the third inner model test employed GoF. A GoF value of 0.10 is considered small, while a GoF value of 0.25 is considered medium and 0.36 is considered large. In this research, the GoF value was 0.682 , which meant that the GoF value was considered large. Based on R-square, Q-square, and GoF evaluations, it can be concluded that the proposed structural model was robust, so that hypothesis testing could be conducted. Table 4 summarizes the results of the inner model evaluation.

Table 4 - Summary of Inner Model Evaluation

\begin{tabular}{|c|c|c|}
\hline Variable & R-square & Q-square \\
\hline WOM Behavior (WOM) & 0.478 & 0.343 \\
\hline Customer Satisfaction (CS) & 0.688 & 0.472 \\
\hline Continuance Intention (Cl) & 0.481 & 0.358 \\
\hline \multicolumn{2}{|c|}{ GoF $=\sqrt{0.707 \times 0.658}=0.682$} \\
\hline
\end{tabular}

Decision on hypothesis acceptance in this research was made with the provision of value of $\mathrm{t}$-distribution table (two-tailed) specified in this research, which was 1.96 for a significance level of 0.05 . PLS score calculation shows that all t-statistics were less than 1.96 , with $p$-values less than 0.05 at $95 \%$ confidence level. This result was enough to reject 
H0. In conclusion, these results supported Hypotheses 1 to 5 . A summary of the hypotheses tests is shown in Table 5.

Table 5 - Hypothesis test

\begin{tabular}{|c|c|c|c|c|c|c|}
\hline $\begin{array}{c}\text { Hypo- } \\
\text { thesis }\end{array}$ & Path & $\begin{array}{c}\text { Original } \\
\text { Sample } \\
(\mathrm{O})\end{array}$ & $\begin{array}{c}\text { Sample } \\
\text { Mean } \\
(\mathrm{M})\end{array}$ & $\begin{array}{c}\text { Standard } \\
\text { Deviation } \\
(\mathrm{STDEV})\end{array}$ & $\begin{array}{c}\text { T Statistics } \\
(|\mathrm{O} / \mathrm{STDEV}|)\end{array}$ & $\mathrm{P}$ Values \\
\hline $\mathrm{H} 1$ & $\begin{array}{c}\text { Bank 4.0 Experiential } \\
\rightarrow \text { WOM Behavior }\end{array}$ & 0.380 & 0.381 & 0.049 & 7.683 & $0.000^{*}$ \\
\hline $\mathrm{H} 2$ & $\begin{array}{c}\text { Bank 4.0 Experiential } \\
\rightarrow \text { Customer Satisfaction }\end{array}$ & 0.796 & 0.797 & 0.016 & 48.409 & $0.000^{*}$ \\
\hline $\mathrm{H} 3$ & $\begin{array}{c}\text { Customer Satisfaction } \\
\rightarrow \text { WOM Behavior }\end{array}$ & 0.391 & 0.389 & 0.052 & 7.554 & $0.000^{*}$ \\
\hline $\mathrm{H} 4$ & $\begin{array}{c}\text { Customer Satisfaction } \\
\rightarrow \text { Continuance Intention }\end{array}$ & 0.355 & 0.357 & 0.049 & 7.249 & $0.000^{*}$ \\
\hline $\mathrm{H} 5$ & $\begin{array}{c}\text { Bank 4.0 Experiential } \\
\rightarrow \text { Continuance Intention }\end{array}$ & 0.411 & 0.408 & 0.047 & 8.736 & $0.000^{*}$ \\
\hline
\end{tabular}

* Significant at $p$ value $<0,05$.

\section{DISCUSSION OF RESULTS}

The main purpose of this research was to answer the problems that were constructed systematically in research questions. Based on the theories and assumptions that were made and empirical data that were successfully collected, the results of the research and their implications can be obtained and will be explained in this section. Bank 4.0 experiential quality (BEQ) was discovered to have a direct effect on WOM behavior. This finding support previous research (Koenig-Lewis \& Palmer, 2008; Klaus \& Maklan, 2013). Furthermore, BEQ was also found to have a direct effect on customer satisfaction. The result also supports previous research (Anderson \& Mittal, 2000; Klaus \& Maklan, 2013; Garg et al, 2014; Mbama et al, 2018). Customer satisfaction was found to have a direct effect on WOM behavior in the sector of Bank 4.0. As such, the result contributes to reinforcing previous research, which stated that customer satisfaction had a positive effect on WOM behavior (Blodgett et al, 1993; Heckman and Guskey, 1998; Gremler \& Brown, 1996), as well as refuting the results of research conducted by Arnett et al (2003) and Bettencourt (1997), which did not find the effect of customer satisfaction on WOM behavior. Moreover, BEQ was discovered to have a direct effect on continuance intention. This finding also supports previous research (Amin et al, 2013; Garg \& Rahman, 2010; Fornell et al, 2006; Klaus \& Maklan, 2013).

Some research relating to online banking usually relies on SERVQUAL or Theory of Technology Acceptance Model (TAM). However, this research relied on S-D Logic theory and thus, contributing to enrich S-D Logic literature. This research has developed a research framework that can support further studies of Bank 4.0, customer experience, and marketing performance. Although there have been many previous studies discussing digital banking and customer experience, there has been no comprehensive research on Bank 4.0 experiential quality in Indonesia. This research contributed to knowledge in the study of Bank 4.0 (King, 2018), e-banking (Nguyen, 2020; Mbama et al., 2018; Keisidou et al., 2013; Howcroft et al., 2002; Harrison et al., 2014), millennial customers ( Kim \& Yang, 2020; Korobka, 2018; Lenhart et al, 2015; Fromm \& Garton, 2013; Smith, 2011; Prensky, 2001), and customer experience (Tran, 2020; Klaus \& Maklan, 2013; Mbama et al., 2018). Several previous studies have tried to understand customer experience, satisfaction, and loyalty (Klaus \& Maklan, 2013; Garg et al., 2014; Piyathasanan et al., 2015); financial performance (Mbama et al, 2018); satisfaction, loyalty and financial performance with no experience variable (Keisidou et al, 2013), but have not paid attention to the relationship between experience and WOM behavior. Klaus and Maklan (2013) attempted to fill the research gap and comprehensively involved experience, loyalty, satisfaction, and WOM behavior in their research. Unfortunately, their research is too general and not suitable for Bank 4.0 sector that does not require physical contact with customers. In addition, Klaus and Maklan (2013) 
failed to explain the variables of loyalty intention and WOM behavior, as evidenced by research on the two variables that was overlapping and ambiguous. This research attempted to fill this gap and comprehensively involved experience, satisfaction, intention, and WOM behavior. In this research, loyalty variable was explicitly separated into two variables, namely, continuance intention and WOM behavior.

\section{CONCLUSION AND SUGGESTIONS}

Based on the constituent indicators of Bank 4.0 experiential quality variables, it can be concluded that Bank 4.0 experiential quality can trigger WOM behavior, customer satisfaction, and continuance intention of millennial customers. The high experiential quality when millennial customers use Bank 4.0 services may trigger them to use the Bank 4.0 application repeatedly, be satisfied, improve the intention to continue using Bank 4.0 services, and make Bank 4.0 the first choice in conducting financial transactions.

To obtain research data, questionnaires were distributed via WhatsApp group(s). During data collection process, there were problems that commonly occur in questionnaire instrument, such as low response rates and lack of anonymity (Ritter \& Sue, 2007). Also found were problems where the data were invalid because the questionnaires were not filled out correctly or the answers did not reflect the millennial profile. The questionnaires employed closed-ended questions that can limit respondents from giving their own opinions, meaning that the answers given did not fully reflect their opinions. The sampling method was purposive sampling, which is a cost-effective way of collecting data, but can be exposed to the risk of under-represented groups of respondents. Demographic distribution was still limited in the Malang region. By online method, this survey could actually be conducted in a wider area with a larger sample size, but in the face of time and resource constraints, it was not possible. The location of this research needs to be extended to several regions in Indonesia. With the help of social media, it is very possible to do. The proportion of financially independent millennial respondents also needs to be increased in order to be a counterbalance and produce more comprehensive research. This research may also be developed by a mixed method, which is by conducting interviews with the officials of Bank 4.0 (commercial banks and fintech companies), regulators, and customers so that a comparison can be obtained. Further research can be developed with new dimensions that may emerge along with the development of Bank 4.0. The conceptual framework of this research can be applied by Bank 4.0 actors (in both commercial banks and fintech companies) by using their customer database to develop marketing strategies and verify how the experiential quality of bank performance is. The framework model will be useful for predicting future sales and profitability of Bank 4.0. The framework can also be adopted, replicated, or applied to other financial businesses.

\section{REFERENCES}

1. Akinci, S., Aksoy, S. \& Atilgan, E. (2003). Adoption of Internet Banking among Sophisticated Consumer Segments in an Advanced Developing Country. International Journal of Bank Marketing, 22(3), 212-232.

2. Ali, H., \& Purwandi, L., (2016). Indonesia 2020: The Urban Middle Class Millennials. Jakarta. Alvara Research Centre.

3. Amin, Muslim. (2016), "Internet banking service quality and its implication on e-customer satisfaction and e-customer loyalty", Int. Journal of Bank Marketing, Vol 34, 280-306.

4. Anderson, E. W., \& Mittal, V. (2000). Strengthening the satisfaction-profit chain. Journal of Service research, 3(2), 107-120.

5. Andert, Darlene. (2011) "Alternating Leadership as a Proactive Organizational Intervention: Addressing the Needs of the Baby Boomers, Generation Xers and Millennials," Journal of Leadership, Accountability and Ethics, Vol. 8, Iss. 4, pp. 67-8. 
6. Arnett, D. B., German, S. D., \& Hunt, S. D. (2003). The Identity Salience Model of Relationship Marketing Success: The Case of Nonprofit Marketing. Journal of Marketing, 67(2), 89-105. doi:10.1509/jmkg.67.2.89.18614

7. Berry, L.L., Bolton, R.N., Bridges, C. H., Meyer, J., Parasuraman, A. \& Seiders, K. (2010). Opportunities for innovation in the delivery of interactive retail services. Journal of Interactive Marketing, 24(2), 155-167.

8. Bettencourt, L. A. (1997). Customer voluntary performance: Customers as partners in service delivery. Journal of retailing, 73(3), 383.

9. Bhattacherjee, A. (2001). Understanding information systems continuance: an expectation-confirmation model. MIS quarterly, 351-370.

10. Blodgett, J. G. (1993). The effects of perceived justice on complainants' negative wordof-mouth behavior and repatronage intentions. Journal of retailing, 69(4), 399.

11. Brakus, J.J, Schmitt, B.H, Zarantonello. (2009). Brand experience: what is it? How is it measured? Does it affect loyalty? Journal of marketing Vol. 73 (May 2009), 52-68

12. Brown, T. J., Barry, T. E., Dacin, P. A., \& Gunst, R. F. (2005). Spreading the word: Investigating antecedents of consumers' positive word-of-mouth intentions and behaviors in a retailing context. Journal of the academy of marketing science, 33(2), 123-138.

13. Burstein, David.D. (2013). Fast Future: How the Millennial Generation Is Shaping Our World. Beacon Press Boston

14. Chang, S-H \& Lin, R. (2015). Building a Total Customer Experience Model: Applications for the Travel Experiences in Taiwan's Creative Life Industry. Journal of Travel \& Tourism Marketing, 32(4), 438-453.

15. Chin, W. W. (2010). How to write up and report PLS analyses. In Handbook of partial least squares (pp. 655-690). Springer, Berlin, Heidelberg.

16. Chin, W. W., Peterson, R. A., \& Brown, S. P. (2008). Structural equation modelling in marketing: Some practical reminders. Journal of Marketing Theory and Practice, 16(4), 287-298. doi:10.2753/MTP1069-6679160402

17. Dootson, P., Beatson, A. \& Drennan, J. (2016). Financial Institutions using Social Media - Do Consumers Perceive Value? International Journal of Bank Marketing, 34(1), 9-36.

18. Fathollahzadeh, M., Hashemi, A. \& Kahreh, M.S. (2011). Designing a new model for determining Customer Value, Satisfaction and Loyalty towards Banking Sector of Iran. European Journal of Economics, Finance and Administrative Sciences, 28 (1), 126-138.

19. Fornell, C., \& Larker, D. (1981). Structural equation modeling and regression: guidelines for research practice. Journal of Marketing Research, 18(1), 39-50.

20. Fornell, C., Mithas, S., Morgeson III, F. V., \& Krishnan, M. S. (2006). Customer satisfaction and stock prices: High returns, low risk. Journal of marketing, 70(1), 3-14.

21. Fromm, Jeff, and Christie Garton. (2013). Marketing to millennials: Reach the largest and most influential generation of consumers ever. Amacom.

22. Garg, R., Rahman, Z. and Qureshi, M.N. (2014), "Measuring customer experience in banks: scale development and validation", Journal of Modelling in Management, Vol. 9 No. 1, pp. 87-117.

23. Garg, R., Rahman, Z., \& Kumar, I. (2010). Evaluating a model for analyzing methods used for measuring customer experience. Journal of Database Marketing \& Customer Strategy Management, 17(2), 78-90

24. Ghozali, I. (2014). SEM Metode Alternatif dengan menggunakan Partial Least Squares (PLS). Semarang: Badan Penerbit Universitas Diponegoro

25. Gremler, D. D., \& Brown, S. W. (1996). Service loyalty: its nature, importance, and implications. Advancing service quality: A global perspective, 5(1), 171-181.

26. Hair, J. F., Jr, Hult, G. T. M., Ringle, C. M., \& Sarstedt, M. (2014). A primer on partial least squares structural equation modeling (PLS-SEM). Los Angeles, US: Sage Publications.

27. Hair, J. F., Ringle, C. M., \& Sarstedt, M. (2013). Partial least squares structural equation modeling: Rigorous applications, better results and higher acceptance. Long range planning, 46(1-2), 1-12. 
28. Harrison-Walker, L. J. (2001). The measurement of word-of-mouth communication and an investigation of service quality and customer commitment as potential antecedents. Journal of service research, 4(1), 60-75.

29. Heckman, R., \& Guskey, A. (1998). Sources of customer satisfaction and dissatisfaction with information technology help desks. Journal of Market-Focused Management, 3(1), 59-89.

30. Hosany, S., \& Gilbert, D. (2009). Dimensions of Tourists' Emotional Experiences Towards Hedonic Holiday Destinations. SSRN Electronic Journal. doi:10.2139/ssrn.1871768

31. Howcroft, B., Hamilton, R., \& Hewer, P. (2002). Consumer attitude and the usage and adoption of home-based banking in the United Kingdom. International journal of bank marketing.

32. Jun, M., \& Palacios, S. (2016). Examining the key dimensions of mobile banking service quality: an exploratory study. International Journal of Bank Marketing.

33. Kaifi, Belal.A., Nafei, Wageeh A., Khanfar, Nile.M., Kaifi, Maryam. M. (2012). MultiGenerational Workforce: Managing and Understanding Millennials. International Journal of Business and Management; Vol. 7, No. 24.

34. Karatepe, O. M., Yavas, U. \& Babakus, E. (2005). Measuring Service Quality of Banks: Scale Development and Validation. Journal of Retailing and Consumer Services, 12(5), 373-383.

35. Keisidou, E., Sarigiannidis, L., Maditinos, D.I. and Thalassinos, E.I. (2013), "Customer satisfaction, loyalty and financial performance", International Journal of Bank Marketing, Vol. 31 No. 4, pp.259-288.

36. Kim, M. J. (2019). Does customer delight matter in the customer satisfaction-loyalty linkage. Journal of Asian Finance, Economics and Business, 6(3), 235-245.

37. KIM, Y. E., \& YANG, H. C. (2020). The effects of perceived satisfaction level of highinvolvement product choice attribute of Millennial generation on repurchase intention: Moderating effect of gender difference. The Journal of Asian Finance, Economics, and Business, 7(1), 131-140.

38. King, Brett. (2018). Bank 4.0: Banking Everywhere Never at a Bank, Marshall Cavendish Business, Singapore.

39. Klaus, P. P., \& Maklan, S. (2013). Towards a better measure of customer experience. International Journal of Market Research, 55(2), 227-246.

40. Knutson, B. J., Beck, J. A., Kim, S. H. \& Cha, J. (2007). Identifying the Dimensions of the Experience Construct. Journal of Hospitality Marketing \& Management, 15(3), 3147.

41. Koenig-Lewis, N., \& Palmer, A. (2008). Experiential values over time-a comparison of measures of satisfaction and emotion. Journal of marketing management, 24(1-2), 69-85.

42. Korobka, Tanya. "The Ultimate List of Millennial Characteristics." Lucky Attitude (2018).

43. Kotler, P. (2003). Marketing insights from A to Z: 80 concepts every manager needs to know. John Wiley \& Sons.

44. Lee, K. C. \& Chung, N. (2009). Understanding Factors Affecting Trust in and Satisfaction with Mobile Banking in Korea: A Modified DeLone and McLean's model perspective. Interacting with Computer, 21(5/6), 385-392.

45. Lenhart, A., Purcell, K., Smith, A., \& Zickuhr, K. (2010). Pew Research Centre. 2010 Feb 03. Social Media and Mobile Internet among Teens and Young Adults URL: http://www. pewinternet.org/2010/02/03/part-4-the-internet-as-an-information-and-economicappliance-in-the-lives-of-teens-and-young-adults

46. Levy, S. \& Hino, H. (2016). Emotional Brand Attachment: A Factor in Customer-Bank Relationships. International Journal of Bank Marketing, 34(2), 136-150.

47. Liang, C. J. (2009). The influence of customer perceptions on financial performance in financial services. International Journal of Bank Marketing.

48. Limayem, M. (2011). Predicting the continued use of Internet-based learning technologies: the role of habit. Behaviour \& Information Technology, 30(1), 91-99.

49. Malhotra, N. K., \& Malhotra, N. K. (2012). Basic marketing research: Integration of social media. Boston: Pearson. 
50. Martins, C., Oliveira, T. \& Popovic, A. (2014). Understanding the Internet Banking Adoption: A Unified Theory of Acceptance and Use of Technology and Perceived Risk Application. International Journal of Information Management, 34(1), 1-13.

51. Mbama, C. I., \& Ezepue, P. O. (2018). Digital banking, customer experience and bank financial performance., UK customer's perception. International Journal of Bank Marketing, 36(2), 230-255. doi:10.1108/ijbm-11-2016-0181

52. Mbama, C.I, Ezepue, P, Alboul, L, and Beer, M. (2018). "Digital banking, customer experience and financial performance: UK bank managers' perceptions", Journal of Research in Interactive Marketing, Vol. 12 Issue: 4, pp.432-451

53. Monferrer-Tirado, D., Estrada-Guillén, M., Fandos-Roig, J. C., Moliner-Tena, M. A. and Sánchez G. J. (2016). Service Quality in Bank During an Economic Crisis. International Journal of Bank Marketing, 34(2), 235-259.

54. Nguyen, O. T. (2020). Factors Affecting the Intention to Use Digital Banking in Vietnam. The Journal of Asian Finance, Economics, and Business, 7(3), 303-310.

55. Nigam, D. A. (2012). Modeling Relationship between Experiential Marketing, Experiential Value and Purchase Intensions in Organized Quick Service Chain Restaurants Shoppers Using Structural Equation Modeling Approach. Paradigm, 16(1), 70-79. doi:10.1177/0971890720120108.

56. Oh, L.-B., \& Teo, H.-H. (2010). Consumer Value Co-creation in a Hybrid Commerce Service-Delivery System. International Journal of Electronic Commerce, 14(3), 35-62. doi:10.2753/jec1086-4415140303.

57. Oliver, R. L. (1980). A cognitive model of the antecedents and consequences of satisfaction decisions. Journal of marketing research, 17(4), 460-469.

58. Otto, J. E., \& Ritchie, J. R. B. (1996). The service experience in tourism. Tourism Management, 17(3), 165-174. doi:10.1016/0261-5177(96)00003-9.

59. Piyathasanan, Bhuminan, Christine Mathies, Martin Wetzels, Paul G. Patterson, and Ko de Ruyter. (2015). "A hierarchical model of virtual experience and its influences on the perceived value and loyalty of customers." International Journal of Electronic Commerce 19, no. 2: 126-158.

60. Prensky, Marc (2001). Digital Natives, Digital Immigrants. On the Horizon, MCB University Press, Vol. 9.

61. Ritter, L. A., \& Sue, V. M. (2007). Introduction to using online surveys. New Directions for Evaluation, 2007(115), 5-14.

62. Rogers, E. (2003). Diffusion of Innovation (5th ed.). New York, NY: Free Press.

63. Schmitt, B. (1999). Experiential Marketing. Journal of Marketing Management, 15(1-3), 53-67. doi:10.1362/026725799784870496.

64. Sharma, N. and Patterson, P.G. (2000). Switching costs, alternative attractiveness and experience as moderators of relationship commitment in professional consumer services, International Journal of Service Industry Management, 11(5), 470-490.

65. Smith, Aaron. (2011). Why Americans use social media. Washington, DC: Pew Internet \& American Life Project.

66. Tran, V. D. (2020). Assessing the effects of service quality, experience value, relationship quality on behavioral intentions. The Journal of Asian Finance, Economics, and Business, 7(3), 167-175.

67. Vargo, Stephen L. \& Lusch, R.F. (2008). Service-dominant logic: continuing the evolution. Journal of the Academy of Marketing Science. Vol.36. p.1-10.

68. Ventures, M. D. I. (2017). Mobile Payments in Indonesia: Race to Big Data Domination.

69. Vesel, P., \& Zabkar, V. (2009). Managing customer loyalty through the mediating role of satisfaction in the DIY retail loyalty program. Journal of Retailing and consumer Services, 16(5), 396-406.

70. Wu, L. W. (2011). Beyond Satisfaction: The Relative Importance of Locational Convenience, Interpersonal Relationships, and Commitment across Service Types. Managing Service Quality, 21(3), 240-263.

71. Zemke, R., Raines, C., \& Filipczak, B. (2000). Generations at work: Managing the clash of Veterans, Boomers, Xers, and Nexters in your workplace. 